\title{
Bacillus seohaeanensis sp. nov., a halotolerant bacterium that contains L-lysine in its cell wall
}

\author{
Correspondence \\ Chang-Jin Kim \\ changjin@kribb.re.kr
}

\author{
Jae-Chan Lee, ${ }^{1}$ Jee-Min Lim, ${ }^{1}$ Dong-Jin Park, ${ }^{1}$ Che Ok Jeon, ${ }^{2}$ \\ Wen-Jun $\mathrm{Li}^{3}$ and Chang-Jin Kim ${ }^{1}$ \\ ${ }^{1}$ Korea Research Institute of Bioscience and Biotechnology, 52 Oeundong, Yusong, \\ Daejeon 305-333, Republic of Korea \\ 2Division of Environmental Biotechnology, PMBBRC, Gyeongsang National University, \\ Jinju 660-701, Republic of Korea \\ ${ }^{3}$ The Key Laboratory for Microbial Resources of Ministry of Education, Yunnan Institute of
Microbiology, Yunnan University, Kunming 650091, PR China
}

\begin{abstract}
A halotolerant, round-endospore-forming, aerobic, Gram-positive bacterium, designated $\mathrm{BH} 724^{\top}$, was isolated from a solar saltern at Taean in Korea. Cells of this strain were rod-shaped and found to be non-motile. Strain $\mathrm{BH} 724^{\top}$ grew at salinities of $0-10 \%(w / v) ~ N a C l$ with an optimum of $3 \%(\mathrm{w} / \mathrm{v}) \mathrm{NaCl}$ and at temperatures of $15-50^{\circ} \mathrm{C}$ with an optimum of $40{ }^{\circ} \mathrm{C}$. Phylogenetic analyses based on 16S rRNA gene sequences showed that strain $\mathrm{BH} 724^{\top}$ belonged to the genus Bacillus and that Bacillus aquimaris TF- $12^{\top}$, Bacillus marisflavi TF- $11^{\top}$ and Bacillus vietnamensis JCM $11124^{\top}$ were its closest neighbours, sharing $97 \cdot 3,97 \cdot 2$ and $97 \cdot 0 \% 16 \mathrm{~S}$ rRNA gene sequence similarity, respectively. The genomic DNA G $+\mathrm{C}$ content was $39 \mathrm{~mol} \%$ and the predominant menaquinone was MK-7. Its major cellular fatty acids were anteiso- $C_{15: 0,}$, iso- $_{15: 0}$, iso- $C_{16: 0}$ and iso- $C_{14: 0}$. The peptidoglycan type was $A 1 \alpha$, linked directly through L-lysine. On the basis of morphological, chemotaxonomic, physiological and phylogenetic properties, strain $\mathrm{BH} 724^{\top}$ represents a novel species of the genus Bacillus, for which the name Bacillus seohaeanensis sp. nov. is proposed. The type strain is $\mathrm{BH} 724^{\top}\left(=\mathrm{KCTC} 3913^{\top}=\mathrm{DSM} 16464^{\top}\right)$.
\end{abstract}

The presence of a considerable diversity of organisms, constituting both moderately halophilic as well as halotolerant bacteria, has been revealed from extreme environments such as hypersaline environments (Ventosa et al., 1998; Oren, 1999, Yoon et al., 2001a, 2003). Aerobic, rodshaped, endospore-forming, halophilic and/or halotolerant Gram-positive bacteria were originally classified in the genus Bacillus, but recently they have been reclassified as members of new genera or transferred to other genera by the application of molecular methods and improved phenotypic approaches (Arahal et al., 2000; Ash et al., 1993; Heyndrickx et al., 1998; Jeon et al., 2005; Schlesner et al., 2001; Shida et al., 1996; Wainø et al., 1999; Yoon et al., 2001b). In the course of screening halophilic bacteria, we isolated a halotolerant bacterium belonging to the genus Bacillus. The results of a polyphasic characterization of this Bacillus strain, $\mathrm{BH} 724^{\mathrm{T}}$, are presented here. Our results suggest that the strain represents a novel species of the genus Bacillus.

Strain $\mathrm{BH} 724^{\mathrm{T}}$ was isolated from a solar saltern at Taean on the west coast of Korea. For isolation, soil samples were diluted serially with $1 \%(\mathrm{w} / \mathrm{v})$ saline solution, spread on

The GenBank/EMBL/DDBJ accession number for the 16S rRNA gene sequence of strain $\mathrm{BH} 724^{\top}$ is $\mathrm{AY} 667495$. marine agar 2216 (MA; Difco) with a final concentration of $11.4 \%(\mathrm{w} / \mathrm{v})$ total salts and incubated for 2 days at $35^{\circ} \mathrm{C}$. Isolate $\mathrm{BH} 724^{\mathrm{T}}$ was routinely grown aerobically on MA for 2 days at $35^{\circ} \mathrm{C}$ except where indicated otherwise. Requirements for, and tolerance of, $\mathrm{NaCl}$ were determined in nutrient broth supplemented with modified artificial seawater containing $\left(\mathrm{l}^{-1}\right)$ : $0-30 \%(\mathrm{w} / \mathrm{v}) \mathrm{NaCl}, 5.94 \mathrm{~g}$ $\mathrm{MgSO}_{4} .7 \mathrm{H}_{2} \mathrm{O}, 4.53 \mathrm{~g} \mathrm{MgCl}_{2} \cdot 6 \mathrm{H}_{2} \mathrm{O}, 0.64 \mathrm{~g} \mathrm{KCl}$ and $1.3 \mathrm{~g}$ $\mathrm{CaCl}_{2} \cdot 2 \mathrm{H}_{2} \mathrm{O}$ (Levring, 1946). Growth was tested at different temperatures $\left(4-55^{\circ} \mathrm{C}\right)$ and $\mathrm{pH}$ values $(5 \cdot 0-10 \cdot 0)$ in marine broth (MB; Difco). To test for growth on single carbon sources at a concentration of $10 \mathrm{~g} \mathrm{l}^{-1}$, yeast extract and peptone were omitted from the MB. Cell growth was monitored by measurement of optical density at $600 \mathrm{~nm}$. The cellular biomass of strain $\mathrm{BH} 724^{\mathrm{T}}$ was obtained from $\mathrm{MB}$ cultures at $35^{\circ} \mathrm{C}$.

Cell morphology was studied using light microscopy and transmission electron microscopy. Motility was observed at 12 and $36 \mathrm{~h}$ in wet mounts under a light microscope (Nikon E600). The flagellum type was examined by transmission electron microscopy using cells from the exponential growth phase. Cells were mounted on Formvar-coated copper grids and negatively stained with $1 \%$ potassium phosphotungstate $(\mathrm{pH} \mathrm{7 \cdot 0)}$. Grids were examined in a Phillips 201 
transmission electron microscope operating at $80 \mathrm{kV}$. Endospores were stained according to the method of Schaeffer-Fulton (Smibert \& Krieg, 1981).

Gram staining was determined using the bioMérieux Gram Stain kit according to the manufacturer's instruction. Catalase activity was determined by bubble production in $3 \%(\mathrm{v} / \mathrm{v})$ aqueous hydrogen peroxide solution. Oxidase activity was tested by oxidation of $1 \%(\mathrm{w} / \mathrm{v})$ tetramethyl-pphenylenediamine using a Bactident Oxidase strip (Merck). Nitrate reduction and hydrolysis of aesculin, casein, starch, Tween 80, urea, hypoxanthine, tyrosine, gelatin and xanthine were determined on MA according to the methods described by Cowan \& Steel (1965), Lanyi (1987) and Smibert \& Krieg (1994). Acid production from carbohydrates was tested as described by Leifson (1963). Growth under anaerobic conditions was determined in an anaerobic chamber $\left(5 \% \mathrm{H}_{2}, 10 \% \mathrm{CO}_{2}, 85 \% \mathrm{~N}_{2}\right.$; Mart Microbiology) after 5 days' incubation at $35^{\circ} \mathrm{C}$ on MA.

For quantitative analysis of whole-cell fatty acids, strain BH724 $4^{\mathrm{T}}$ was cultivated on MA for 2 days at $30^{\circ} \mathrm{C}$. Fatty acid methyl esters were analysed by GC/MS according to the instructions of the Microbial Identification System (MIDI; Microbial ID). Isoprenoid quinones were analysed as described by Komagata \& Suzuki (1987) using HPLC apparatus fitted with a reversed-phase column (GROM-SIL 100 ODS-2FE; Grom). Methanol/2-propanol (2:1, v/v) was used as the mobile phase and quinone was detected at $270 \mathrm{~nm}$. The peptidoglycan structure was elucidated by the DSMZ Identification Service. Qualitative analyses of amino acids and peptides in peptidoglycan hydrolysates were carried out as described by Schleifer (1985) and Schleifer \& Kandler (1972) with paper chromatography (Rhuland et al.,

Table 1. Phenotypic characteristics that differentiate strain $B H 724^{\top}$ from related members of the genus Bacillus

Data from Noguchi et al. (2004), Yoon et al. (2003) and this study. +, Positive; -, negative; W, weakly positive; V, variable; ND, no data available; DAP, diaminopimelic acid. All of the micro-organisms were positive for the hydrolysis of casein.

\begin{tabular}{|c|c|c|c|c|}
\hline Characteristic & $\mathrm{BH} 724^{\mathrm{T}}$ & B. marisflavi & B. aquimaris & B. vietnamensis \\
\hline Gram staining & + & $+($ or $\mathrm{V})$ & $\mathrm{V}$ & + \\
\hline Colony colour & Cream & Pale yellow & Pale orange/yellow & ND \\
\hline Cell size $(\mu \mathrm{m})$ & $0 \cdot 5-0 \cdot 6 \times 1 \cdot 3-1 \cdot 8$ & $0 \cdot 6-0 \cdot 8 \times 1 \cdot 5-3 \cdot 5$ & $0 \cdot 5-0 \cdot 7 \times 1 \cdot 2-3 \cdot 5$ & $0 \cdot 5-1 \cdot 7 \times 2 \cdot 0-3 \cdot 0$ \\
\hline Spore position & Central & Subterminal or central & Central & Central \\
\hline Spore shape & Sphere & Ellipsoid & Ellipsoid & Ellipsoid \\
\hline Motility & - & + & + & + \\
\hline \multicolumn{5}{|l|}{ Growth in/at } \\
\hline $10{ }^{\circ} \mathrm{C}$ & - & + & + & + \\
\hline $50{ }^{\circ} \mathrm{C}$ & + & - & - & - \\
\hline $\mathrm{pH} 4 \cdot 5$ & - & + & - & - \\
\hline $\mathrm{pH} 9 \cdot 0$ & - & + & - & + \\
\hline $0 \% \mathrm{NaCl}$ & + & + & $\mathrm{W}$ & + \\
\hline $15 \%(\mathrm{w} / \mathrm{v}) \mathrm{NaCl}$ & - & + & + & + \\
\hline Oxidase & + & - & - & + \\
\hline \multicolumn{5}{|l|}{ Hydrolysis of: } \\
\hline Aesculin & + & + & - & + \\
\hline Tween 80 & - & - & + & ND \\
\hline Starch & - & - & + & + \\
\hline Urea & + & - & - & ND \\
\hline \multicolumn{5}{|l|}{ Acid production from: } \\
\hline Aesculin & + & + & - & + \\
\hline Arbutin & + & + & - & - \\
\hline Glycerol & + & + & - & + \\
\hline D-Mannitol & + & + & - & + \\
\hline D-Mannose & $\mathrm{W}$ & + & - & - \\
\hline Melibiose & - & + & - & - \\
\hline D-Raffinose & - & $\mathrm{W}$ & - & - \\
\hline Salicin & - & + & - & - \\
\hline Starch & - & - & + & + \\
\hline D-Xylose & + & - & - & - \\
\hline Cell wall type & $\mathrm{A} 1 \alpha$ (L-Lys direct) & meso-DAP & meso-DAP & meso-DAP \\
\hline DNA G $+\mathrm{C}$ content $(\mathrm{mol} \%)$ & 39 & 49 & 38 & 43 \\
\hline
\end{tabular}


1955). The quantitative analysis of amino acids in the total hydrolysate was performed by gas chromatography and GC/MS as described by MacKenzie (1987) and Hasegawa et al. (1983). The $\mathrm{N}$ terminus of the interpeptide bridge was determined by dinitrophenylation according to Schleifer (1985). The G $+\mathrm{C}$ content (mol\%) was determined by reversed-phase HPLC using the method of Tamaoka \& Komagata (1984).

DNA-DNA hybridization was carried out to evaluate the genomic DNA relatedness between strain $\mathrm{BH} 724^{\mathrm{T}}$ and closely related type strains of the genus Bacillus. Strains for comparative analysis were grown aerobically on MA for 2 days at $35^{\circ} \mathrm{C}$ and chromosomal DNA was isolated and purified according to the method described by Yoon et al. (1996). DNA-DNA hybridization was determined based on the filter-hybridization method described by Seldin \& Dubnau (1985). Isolated DNA samples were serially diluted from 200 to $0.5 \mathrm{ng}$ and denatured by boiling for $10 \mathrm{~min}$. The series of dilutions was applied to positively charged nylon membranes (Hybond- ${ }^{+}$; Amersham) with a slot device (Schleicher \& Schuell) under a slight vacuum. Random-primed DNA labelling with digoxigenin-dUTP and hybridization were performed using a DIG-High Prime DNA Labelling kit and hybridization solutions (Roche Applied Science) according to the manufacturer's instructions. Detection of hybrids on the nylon membrane was performed using the enzyme immunoassay Detection Starter kit II (Roche Applied Science). Membranes were incubated in $5 \mathrm{ml}$ freshly prepared Colorsubstrate solution (Roche Applied Science) for $16 \mathrm{~h}$ in the dark. The membranes were washed with distilled water and the colour intensities of the series of dilutions were quantified using Bio-Rad GelDoc scanning software. The signals produced by self-hybridization were taken as $100 \%$ and relatedness values (percentages) were calculated from duplicate samples.

The 16S rRNA gene was amplified by PCR using primers Eubac 27F and 1492R (DeLong, 1992) and the PCR products were purified using the QIAquick PCR Purification kit (Qiagen). Sequencing of the purified 16S rRNA gene was performed using an ABI PRISM BigDye Terminator Cycle Sequencing kit (Applied Biosystems), as recommended by the manufacturer, and five primers $(337 \mathrm{~F}, 785 \mathrm{~F}, 1225 \mathrm{~F}$, $518 \mathrm{R}$ and $1100 \mathrm{R})$. The purified sequencing reaction mixtures were electrophoresed automatically using an Applied Biosystems model 377 automatic DNA sequencer. The 16S rRNA gene sequence of strain BA724 $4^{\mathrm{T}}$ was aligned together with those of other Bacillus species using CLUSTAL W (Thompson et al., 1994). Sequence similarity values were computed using Similarity Matrix version 1.1 (Ribosomal Database Project II; http://rdp.cme.msu.edu/) (Cole et al., 2003). Gaps at the $5^{\prime}$ and $3^{\prime}$ ends of the alignment were omitted in further analyses. Phylogenetic trees were inferred using three tree-making algorithms: the neighbour-joining (Saitou \& Nei, 1987), maximum-likelihood (Felsenstein, 1981) and maximum-parsimony (Kluge \& Farris, 1969) methods available in the PHYLIP software package version 3.6
(Felsenstein, 2002). Evolutionary distance matrices for the neighbour-joining method were calculated using the algorithm of the Kimura two-parameter model (Kimura, 1980) with the DNADIST program. To evaluate the stability of the phylogenetic tree, a bootstrap analysis (1000 replications) was performed with the SEQBOOT, DNADIST, NEIGHBOR and CONSENSE programs in the PHYLIP package.

Strain $\mathrm{BH} 724^{\mathrm{T}}$ on MA medium formed creamy, smooth and circular/slightly irregular colonies after incubation at $35^{\circ} \mathrm{C}$ for 2 days. Growth was not observed in the absence of salts. The strain grew at salt concentrations in the range of $0-10 \%$ (w/v) NaCl, with optimum growth occurring at 3-5\% (w/v) $\mathrm{NaCl}$ in the presence of artificial seawater. The strain did not grow in the presence of more than $12 \%(\mathrm{w} / \mathrm{v}) \mathrm{NaCl}$. Growth occurred from $\mathrm{pH} 5 \cdot 0$ to $8 \cdot 0$ (optimum, $\mathrm{pH} 7 \cdot 5$ ) in marine broth. Growth was observed at temperatures between 15 and $50^{\circ} \mathrm{C}$, with an optimum growth temperature of $35-40{ }^{\circ} \mathrm{C}$, and growth was not observed at $10^{\circ} \mathrm{C}$.

Table 2. Cellular fatty acid compositions of strain $B \mathrm{BH} 724^{\top}$ and related species on MA supplemented with $3 \%(\mathrm{w} / \mathrm{v})$ $\mathrm{NaCl}$

Data are expressed as percentages of total fatty acids. Fatty acids representing less than $0.5 \%$ in all strains are not included. ND, Not detected. Data for reference strains were taken from Yoon et al. (2003).

\begin{tabular}{|c|c|c|c|}
\hline Fatty acid & $\mathrm{BH} 724^{\mathrm{T}}$ & B. marisflavi & B. aquimaris \\
\hline \multicolumn{4}{|c|}{ Straight-chain fatty acids } \\
\hline $\mathrm{C}_{14: 0}$ & $0 \cdot 4$ & $1 \cdot 7$ & $0 \cdot 9$ \\
\hline $\mathrm{C}_{15: 0}$ & $0 \cdot 7$ & $1 \cdot 1$ & $0 \cdot 5$ \\
\hline $\mathrm{C}_{16: 0}$ & $1 \cdot 3$ & $1 \cdot 0$ & $0 \cdot 5$ \\
\hline \multicolumn{4}{|l|}{ Branched fatty acids } \\
\hline iso- $\mathrm{C}_{14: 0}$ & $8 \cdot 2$ & $9 \cdot 1$ & $6 \cdot 5$ \\
\hline iso- $\mathrm{C}_{15: 0}$ & $20 \cdot 3$ & $22 \cdot 9$ & $46 \cdot 9$ \\
\hline iso- $\mathrm{C}_{16: 0}$ & $14 \cdot 3$ & $7 \cdot 7$ & $4 \cdot 2$ \\
\hline iso- $\mathrm{C}_{17: 0}$ & $1 \cdot 6$ & $1 \cdot 2$ & $0 \cdot 8$ \\
\hline anteiso- $\mathrm{C}_{15: 0}$ & $36 \cdot 7$ & $27 \cdot 7$ & $22 \cdot 2$ \\
\hline anteiso- $\mathrm{C}_{17: 0}$ & $4 \cdot 8$ & $7 \cdot 1$ & $2 \cdot 3$ \\
\hline \multicolumn{4}{|c|}{ Unsaturated fatty acids } \\
\hline iso- $\mathrm{C}_{15: 1}$ & ND & $\mathrm{ND}$ & $0 \cdot 7$ \\
\hline $\mathrm{C}_{16: 1} \omega 7 c$ alcohol & $4 \cdot 0$ & $2 \cdot 5$ & $8 \cdot 4$ \\
\hline $\mathrm{C}_{16: 1} \omega 11 c$ & $0 \cdot 6$ & ND & $1 \cdot 3$ \\
\hline iso- $\mathrm{C}_{17: 1} \omega 10 c$ & $0 \cdot 4$ & ND & $1 \cdot 8$ \\
\hline \multicolumn{4}{|l|}{ Hydroxy fatty acids } \\
\hline $\mathrm{C}_{15: 0} 2-\mathrm{OH}$ & $1 \cdot 3$ & $5 \cdot 5$ & ND \\
\hline $\mathrm{C}_{17: 0} 2-\mathrm{OH}$ & ND & $1 \cdot 2$ & ND \\
\hline iso- $\mathrm{C}_{14: 0} 3-\mathrm{OH}$ & $1 \cdot 1$ & $2 \cdot 0$ & ND \\
\hline iso- $\mathrm{C}_{15: 0} 3-\mathrm{OH}$ & $1 \cdot 6$ & $6 \cdot 1$ & $\mathrm{ND}$ \\
\hline iso- $\mathrm{C}_{16: 0} 3-\mathrm{OH}$ & $1 \cdot 2$ & $1 \cdot 5$ & ND \\
\hline Summed feature $4^{*}$ & $0 \cdot 9$ & $1 \cdot 8$ & $2 \cdot 9$ \\
\hline
\end{tabular}

* Summed features represent groups of two or three fatty acids that can not be separated by GLC with the MIDI system. Summed feature 4 contains iso- $\mathrm{C}_{17: 1} \mathrm{I}$ and/or anteiso- $\mathrm{C}_{17: 1} \mathrm{~B}$. 


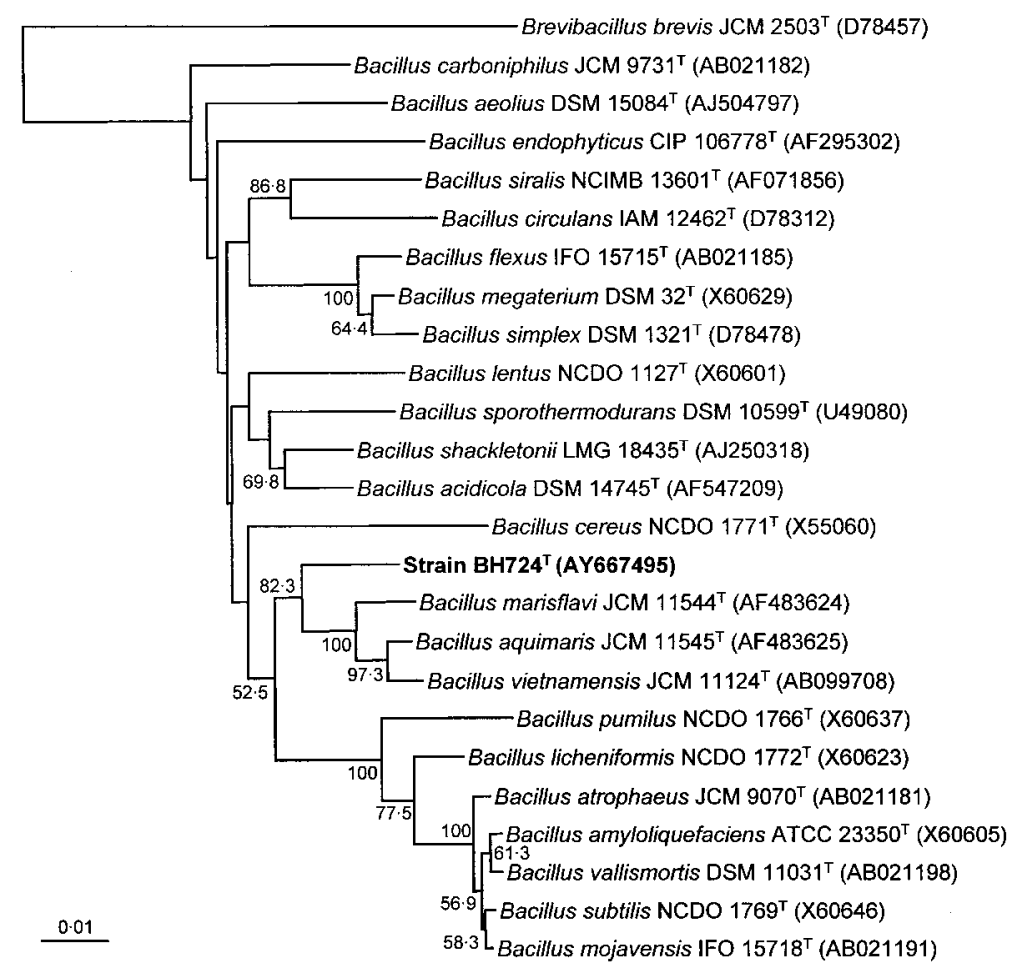

Fig. 1. Neighbour-joining tree based on 16S rRNA gene sequences showing the phylogenetic relationship of strain $\mathrm{BH} 724^{\top}$ to other related taxa. Numbers at branching nodes are bootstrap values (percentages of 1000 replications); only values greater than $50 \%$ are indicated. Bar, 0.01 substitutions per nucleotide position.

Strain $\mathrm{BH} 724^{\mathrm{T}}$ was a Gram-positive, strictly aerobic rod, $0.5-0.6 \mu \mathrm{m}$ wide and $1 \cdot 3-1 \cdot 8 \mu \mathrm{m}$ long. It formed spherical endospores at central positions and cells were non-motile and did not possess flagella. The phenotypic characteristics of strain $\mathrm{BH} 724^{\mathrm{T}}$ are compared with those of type strains of closely related Bacillus species in Table 1.

The predominant isoprenoid quinone was MK-7. The cellular fatty acid profile of strain $\mathrm{BH} 724^{\mathrm{T}}$ was characterized by the presence of branched fatty acids such as anteiso- $\mathrm{C}_{15: 0}$ $(36 \cdot 7 \%)$, iso- $\mathrm{C}_{15: 0}(20 \cdot 3 \%)$ and iso- $\mathrm{C}_{16: 0}(14 \cdot 3 \%)$ as the major fatty acids on MA and its composition was slightly different from that of the other closely related type strains (Table 2). The DNA G $+\mathrm{C}$ content of strain $\mathrm{BH} 724^{\mathrm{T}}$ was $39 \mathrm{~mol} \%$. The major fatty acid profile, major isoprenoid quinone and DNA G $+\mathrm{C}$ content are typical of the group classically defined as the genus Bacillus (Table 1). However, the peptidoglycan of strain $\mathrm{BH} 724^{\mathrm{T}}$ contained the amino acids lysine, alanine and glutamic acid in a molar ratio of $0 \cdot 6: 1 \cdot 8: 1 \cdot 0$. Dinitrophenylation revealed lysine as the only $\mathrm{N}$-terminal amino acid. The peptides L-Ala-D-Glu and L-Lys-D-Ala were detected by two-dimensional TLC in the partial hydrolysate. From these data, it was concluded that the peptidoglycan type is Al $\alpha$ (L-Lys direct) (Schleifer \& Kandler, 1972) (murein type A11 according to the DSMZ catalogue of strains, 2001). The majority of endosporeforming, Gram-positive, rod-shaped bacteria possess mesodiaminopimelic acid as the diagnostic diamino acid of the cell wall peptidoglycan. Therefore, strain $\mathrm{BH} 724^{\mathrm{T}}$ could be distinguished from closely related species within the genus Bacillus based on cellular fatty acid profiles and cell wall peptidoglycan type.
The almost complete 16S rRNA gene sequence (1401 nt) of strain $\mathrm{BH} 724^{\mathrm{T}}$ was obtained and used for an initial BLAST search in GenBank and for phylogenetic analysis. The similarity values of strain $\mathrm{BH} 724^{\mathrm{T}}$ to closely related species with validly published names were Bacillus aquimaris JCM $11545^{\mathrm{T}}(97 \cdot 3 \%)$, Bacillus marisflavi JCM $11544^{\mathrm{T}}(97 \cdot 2 \%)$ and Bacillus vietnamensis JCM $11124^{\mathrm{T}}(97 \cdot 0 \%)$. Similarity values to other type strains of Bacillus species were $95 \cdot 1-$ $96.9 \%$. A tree constructed by neighbour-joining analysis showed that strain $\mathrm{BH} 724^{\mathrm{T}}$ formed a distinct phylogenetic line with a bootstrap value of $82.3 \%$ compared with the closely related type strains $B$. aquimaris JCM $11545^{\mathrm{T}}, B$. marisflavi JCM $11544^{\mathrm{T}}$ and B. vietnamensis JCM $11124^{\mathrm{T}}$ (Fig. 1). The topologies of phylogenetic trees built using the maximum-likelihood and maximum-parsimony algorithms were similar to that of the tree constructed by neighbourjoining analysis (data not shown).

DNA-DNA relatedness between strain $\mathrm{BH} 724^{\mathrm{T}}$ and $B$. aquimaris JCM $11545^{\mathrm{T}}$, B. marisflavi JCM $11544^{\mathrm{T}}$ and $B$. vietnamensis JCM $11124^{\mathrm{T}}$ was about 50,40 and $30 \%$, respectively, and the values were low enough to allocate strain $\mathrm{BH} 724^{\mathrm{T}}$ to a novel species of the genus Bacillus (Wayne, 1994). On the basis of the phenotypic and multiple molecular analyses, we propose that strain $\mathrm{BH} 724^{\mathrm{T}}$ should assigned to the genus Bacillus within a novel species for which the name Bacillus seohaeanensis sp. nov. is proposed.

\section{Description of Bacillus seohaeanensis sp. nov.}

Bacillus seohaeanensis (seo.hae.an.en'sis. N.L. masc. adj. seohaeanensis of Seohaean, the Korean name for the west coast of Korea, where the type strain was isolated). 
Cells are aerobic, Gram-positive, endospore-forming (spherical, central) rods, $0.5-0.6 \times 1.3-1 \cdot 8 \mu \mathrm{m}$. Colonies are creamy, smooth and circular to slightly irregular. Cells are non-motile and do not possess flagella. Grows at salinities of $0-10 \%(\mathrm{w} / \mathrm{v}) \mathrm{NaCl}$. Optimal growth at 3-5\% (w/v) NaCl. No growth occurs in the presence of more than $12 \%(\mathrm{w} / \mathrm{v})$ $\mathrm{NaCl}$. Grows between 15 and $50^{\circ} \mathrm{C}$ (optimum $35-40{ }^{\circ} \mathrm{C}$ ) and from $\mathrm{pH} 5 \cdot 0$ to $8 \cdot 0$ (optimum $\mathrm{pH} 7 \cdot 5$ ) in marine broth. Glucose, fructose, maltose, glycerol, yeast extract and peptone support growth as the single carbon and energy source. Growth does not occur under anaerobic conditions on MA. Oxidase- and catalase-positive. Nitrate is not reduced to nitrite. Aesculin, casein and urea are hydrolysed. Gelatin, starch, L-tyrosine, Tween 80 , xanthine and hypoxanthine are not hydrolysed. Acid is produced from D-glucose, maltose, D-trehalose, D-xylose, D-ribose, glycerol, D-mannitol, D-fructose, arbutin and D-mannose, but not from L-arabinose, D-rhamnose, lactose, adonitol, D-raffinose, D-salicin and D-melibiose. The cell-wall peptidoglycan type is $\mathrm{A} 1 \alpha$ (L-Lys direct). The predominant isoprenoid quinone is MK-7. The major fatty acids are anteiso- $\mathrm{C}_{15: 0}$, iso- $\mathrm{C}_{15: 0}$ and iso- $\mathrm{C}_{16: 0}$. The $\mathrm{G}+\mathrm{C}$ content of the type strain is $39 \mathrm{~mol} \%$.

The type strain is strain $\mathrm{BH} 724^{\mathrm{T}}\left(=\mathrm{KCTC} 3913^{\mathrm{T}}=\mathrm{DSM}\right.$ $\left.16464^{\mathrm{T}}\right)$, isolated from a solar saltern at Taean on the west coast of Korea.

\section{Acknowledgements}

This work was supported by the 21C Frontier Microbial Genomics and Application Centre Programme of the Ministry of Science and Technology, Republic of Korea.

\section{References}

Arahal, D. R., Márquez, M. C., Volcani, B. E., Schleifer, K. H. \& Ventosa, A. (2000). Reclassification of Bacillus marismortui as Salibacillus marismortui comb. nov. Int J Syst Evol Microbiol 50, 1501-1503.

Ash, C., Priest, F. G. \& Collins, M. D. (1993). Molecular identification of rRNA group 3 bacilli (Ash, Farrow, Wallbanks and Collins) using a PCR probe test. Proposal for the creation of a new genus Paenibacillus. Antonie van Leeuwenhoek 64, 253-260.

Cole, J. R., Chai, B., Marsh, T. L. \& 8 other authors (2003). The Ribosomal Database Project (RDP-II): previewing a new autoaligner that allows regular updates and the new prokaryotic taxonomy. Nucleic Acids Res 31, 442-443.

Cowan, S. T. \& Steel, K. J. (1965). Manual for the Identification of Medical Bacteria. London: Cambridge University Press.

DeLong, E. F. (1992). Archaea in coastal marine environments. Proc Natl Acad Sci U S A 89, 5685-5689.

Felsenstein, J. (1981). Evolutionary trees from DNA sequences: a maximum likelihood approach. J Mol Evol 17, 368-376.

Felsenstein, J. (2002). PHYLIP - Phylogeny Inference Package, version 3.6a. Distributed by the author. University of Washington, Seattle, USA.
Hasegawa, T., Takizawa, M. \& Tanida, S. (1983). A rapid analysis for chemical grouping of aerobic actinomycetes. J Gen Appl Microbiol 29, 319-322.

Heyndrickx, M., Lebbe, L., Kersters, K., De Vos, P., Forsyth, G. \& Logan, N. A. (1998). Virgibacillus: a new genus to accommodate Bacillus pantothenticus (Proom and Knight 1950). Emended description of Virgibacillus pantothenticus. Int J Syst Bacteriol 48, 99-106.

Jeon, C. O., Lim, J.-M., Lee, J.-M., Xu, L.-H., Jiang, C.-L. \& Kim, C.-J. (2005). Reclassification of Bacillus haloalkaliphilus Fritze 1996 as Alkalibacillus haloalkaliphilus gen. nov., comb. nov. and the description of Alkalibacillus salilacus sp. nov., a novel halophilic bacterium isolated from a salt lake in China. Int J Syst Evol Microbiol 55, 1891-1896.

Jukes, T. H. \& Cantor, C. R. (1969). Evolution of protein molecules. In Mammalian Protein Metabolism, vol. 3, pp. 21-132. Edited by H. N. Munro. New York: Academic Press.

Kimura, M. (1980). A simple method for estimating evolutionary rates of base substitutions through comparative studies of nucleotide sequences. J Mol Evol 16, 111-120.

Kluge, A. G. \& Farris, F. S. (1969). Quantitative phyletics and the evolution of anurans. Syst Zool 18, 1-32.

Komagata, K. \& Suzuki, K. (1987). Lipid and cell-wall analysis in bacterial systematics. Methods Microbiol 19, 161-208.

Lanyi, B. (1987). Classical and rapid identification methods for medically important bacteria. Methods Microbiol 19, 1-67.

Leifson, E. (1963). Determination of carbohydrate metabolism of marine bacteria. J Bacteriol 85, 1183-1184.

Levring, T. (1946). Some culture experiments with Ulva and artificial seawater. K Fysiogr Sallsk Lund Forh 16, 45-56.

MacKenzie, S. L. (1987). Gas chromatographic analysis of amino acids as the $N$-heptafluorobutyryl isobutyl esters. J Assoc Off Anal Chem 70, 151-160.

Noguchi, H., Uchino, M., Shida, O., Takano, K., Nakamura, L. K. \& Komagata, K. (2004). Bacillus vietnamensis sp. nov., a moderately halotolerant, aerobic, endospore-forming bacterium isolated from Vietnamese fish sauce. Int J Syst Evol Microbiol 54, 2117-2120.

Oren, A. (1999). Bioenergetic aspects of halophilism. Microbiol Mol Biol Rev 63, 334-348.

Rhuland, L. E., Work, E., Denman, R. F. \& Hoare, D. S. (1955). The behaviour of the isomers of $\alpha, \varepsilon$-diaminopimelic acid on paper chromatograms. J Am Chem Soc 77, 4844-4846.

Saitou, N. \& Nei, M. (1987). The neighbor-joining method: a new method for reconstructing phylogenetic trees. Mol Biol Evol 4, 406-425.

Schleifer, K. H. (1985). Analysis of the chemical composition and primary structure of murein. Methods Microbiol 18, 123-156.

Schleifer, K. H. \& Kandler, O. (1972). Peptidoglycan types of bacterial cell walls and their taxonomic implications. Bacteriol Rev 36, 407-477.

Schlesner, H., Lawson, P. A., Collins, M. D., Weiss, N., Wehmeyer, U., Völker, H. \& Thomm, M. (2001). Filobacillus milensis gen. nov., sp. nov., a new halophilic spore-forming bacterium with Orn-D-Glutype peptidoglycan. Int J Syst Evol Microbiol 51, 425-431.

Seldin, L. \& Dubnau, D. (1985). Deoxyribonucleic acid homology among Bacillus polymyxa, Bacillus macerans, Bacillus azotofixans, and other nitrogen-fixing Bacillus strains. Int J Syst Bacteriol 35, 151-154.

Shida, O., Takagi, H., Kadowaki, K. \& Komagata, K. (1996). Proposal for two new genera, Brevibacillus gen. nov. and Aneurinibacillus gen. nov. Int J Syst Bacteriol 46, 939-946.

Smibert, R. M. \& Krieg, N. R. (1981). General characterization. In Manual of Methods for General Bacteriology, pp. 409-443. Edited by P. Gerhardt, R. G. E. Murray, R. N. Costilow, E. W. Nestor, W. A. 
Wood, N. R. Krieg \& G. B. Phillips. Washington DC: American Society for Microbiology.

Smibert, R. M. \& Krieg, N. R. (1994). Phenotypic characterization. In Methods for General and Molecular Bacteriology, pp. 607-654. Edited by P. Gerhardt. Washington, DC: American Society for Microbiology.

Tamaoka, J. \& Komagata, K. (1984). Determination of DNA base composition by reverse-phase high-performance liquid chromatography. FEMS Microbiol Lett 25, 125-128.

Thompson, J. D., Higgins, D. G. \& Gibson, T. J. (1994). CLUSTAL W: improving the sensitivity of progressive multiple sequence alignment through sequence weighting, position-specific gap penalties and weight matrix choice. Nucleic Acids Res 22, 4673-4680.

Ventosa, A., Nieto, J. J. \& Oren, A. (1998). Biology of moderately halophilic aerobic bacteria. Microbiol Mol Biol Rev 62, 504-544.

Wainø, M., Tindall, B. J., Schumann, P. \& Ingvorsen, K. (1999), Gracilibacillus gen. nov., with description of Gracilibacillus halotolerans gen. nov., sp. nov.; transfer of Bacillus dipsosauri to Gracilibacillus dipsosauri comb. nov., and Bacillus salexigens to the genus Salibacillus gen. nov., as Salibacillus salexigens comb. nov. Int J Syst Bacteriol 49, 821-831.
Wayne, L. G. (1994). Actions of the 'Judicial Commission' of the International Committee on Systematic Bacteriology on request for opinions published between January 1985 and July 1993. Int J Syst Bacteriol 44, 177-178.

Yoon, J.-H., Kim, H., Kim, S.-B., Kim, H.-J., Kim, W. Y., Lee, S. T., Goodfellow, M. \& Park, Y.-H. (1996). Identification of Saccharomonospora strains by the use of genomic DNA fragments and rRNA gene probes. Int J Syst Bacteriol 46, 502-505.

Yoon, J.-H., Kang, S.-S., Lee, K.-C., Kho, Y. H., Choi, S. H., Kang, K. H. \& Park, Y.-H. (2001a). Bacillus jeotgali sp. nov., isolated from jeotgal, Korean traditional fermented seafood. Int $J$ Syst Evol Microbiol 51, 1087-1092.

Yoon, J.-H., Weiss, N., Lee, K.-C., Lee, I.-S., Kang, K. H. \& Park, Y.-H. (2001b). Jeotgalibacillus alimentarius gen. nov., sp. nov., a novel bacterium isolated from jeotgal with L-lysine in the cell wall, and reclassification of Bacillus marinus Rüger 1983 as Marinibacillus marinus gen. nov., comb. nov. Int J Syst Evol Microbiol 51, 2087-2093.

Yoon, J.-H., Kim, I.-G., Kang, K. H., Oh, T.-K. \& Park, Y.-H. (2003). Bacillus marisflavi sp. nov. and Bacillus aquimaris sp. nov., isolated from sea of a tidal flat of the Yellow Sea in Korea. Int J Syst Evol Microbiol 53, 1297-1303. 